\title{
IAMJ
}

INTERNATIONAL

AYURVEDIC

MEDICAL JOURNAL

\section{AN EXPERIMENTAL STUDY ON TWO SAMPLES OF KASIS GODANTI BHASMA PREPARED BY DIFFERENT METHODS W.S.R. TO ANEMIA}

\author{
Vidhiya Malviya ${ }^{1}$, R.K. Pati ${ }^{2}$, Anil Nagle ${ }^{3}$ \\ ${ }^{1}$ PG Scholar, ${ }^{2} \mathrm{MD}$ (Ayu.) Professor, ${ }^{3} \mathrm{MD}$ (Ayu.) Professor \& HOD; \\ Dept. Of RSBK, Pt. Khushilal Sharma Govt. Ayurveda College \& Institute, Bhopal, Madhya Pradesh, India
}

Corresponding Author: vidhiya.malviya@gmail.com

https://doi.org/10.46607/iamj.0809012021

(Published online: January 2021)

Open Access

(C) International Ayurvedic Medical Journal, India 2021

Article Received:25/12/2020 - Peer Reviewed:06/01/2021 - Accepted for Publication:16/01/2021

\section{Check for updates}

\section{ABSTRACT}

Introduction: The exploration of pharmacological effect on Ayurvedic drugs are only possible through animal experimentation. For the global acceptance of the Kasis Godanti Bhasma (KGB) - A herbo-mineral formulation of Ayurveda pharmaceutics, there is needs to revalidate the formulation on all aspects from its safety, efficacy, quality control and animal experimentation. Aims and Objectives: 1. To evaluate the efficacy of Kasis Godanti Bhasma $1^{\text {st }}$ and $2^{\text {nd }}$ in Pandu (Anemia). 2. To compare the effectiveness of Kasis Godanti Bhasma $1^{\text {st }}$ and Kasis Godanti Bhasma $2^{\text {nd }}$ in Pandu (Anemia). Material and Methods: Anemia was induced by intra -peritoneal injection of Phenylhydrazine (PHZ) at $40 \mathrm{mg} / \mathrm{kg}$ for 2 days. Rats were divided in six groups of four rats each. The first group is the control group received distillated water. The second group is anemic control group received only Phenylhydrazine at $40 \mathrm{mg} / \mathrm{kg}$ for 2 days. Third and fourth groups received KGB $1^{\text {st }} 500 \mathrm{mg} / \mathrm{kg}$ and $1000 \mathrm{mg} / \mathrm{kg}$ respectively. While fifth and sixth groups received KGB $2^{\text {nd }} 500 \mathrm{mg} / \mathrm{kg}$ and $1000 \mathrm{mg} / \mathrm{kg}$ respectively. The vehicle and the Bhasmas were administered from day 2 to day 15 after Phenylhydrazine administration. Blood samples were collected from the orbital vein on day 0 before Phenylhydrazine administration, and on day 2, 7, 15 after Phenylhydrazine injection. Result and Conclusion: Experimental study of KGB-1 and KGB-2 shows satisfactory result. On comparing result of KGB-1 and KGB-2. KGB-2 with both doses of $500 \mathrm{mg}$ and $1000 \mathrm{mg}$ shows significant result in anti-anemic effect. While in KGB-1, only $500 \mathrm{mg}$ dose shows the significant re- 
sult in anti-anemic effect. On comparing dose of both the samples $500 \mathrm{mg}$ dose of KGB-1 and KGB-2 shows satisfactory result.

Keywords: Experimental study, Kasis Godanti Bhasma-1 ${ }^{\text {st }}$, Kasis Godanti Bhasma-2 ${ }^{\text {nd }}$

\section{INTRODUCTION}

A growing part of this empirical tradition is experimental, which has gained in importance as the field has matured. This maturation brings with it evergreater scientific and methodological demands. Experimentation is the auspices step for the amelioration of Ayurveda science. The exploration of pharmacological effect of Ayurvedic drugs are only possible through animal experimentation. For the global acceptance of the herbo-mineral formulation of Ayurveda drug there is needs to revalidate the formulation on all aspects from its safety, efficacy, quality control and also through animal experimentation.

\section{Aim and Objectives}

1) To evaluate the efficacy of Kasis Godanti Bhasma $1^{\text {st }}$ and $2^{\text {nd }}$ in Pandu (Anemia).

2) To compare the effectiveness of Kasis Godanti Bhasma $1^{\text {st }}$ and Kasis Godanti Bhasma $2^{\text {nd }}$ in Pandu (Anemia).

\section{Material and Method}

Animals: For pharmacological experiments, wistar albino rats of either sex weighing $150-250$ gm used for the study. The animals were collected from the animal house of VNS College of Pharmacy, Bhopal. All the protocol of the experiments and animal usage were discussed in the Institutional Ethical Committee meeting and permission has been obtained to carry out the parameters selected for the study in accordance to CPCSEA guidelines. The research proposal number is $\mathrm{PH} / \mathrm{IAEC} / \mathrm{VNS} / 2 \mathrm{~K} 20 / 03$.

Housing of Animals: Animals were housed in propylene cages under standard laboratory conditions, maintained on a natural light and dark cycle (12 h 12h) and were fed with standard laboratory diet and water ad labium in the same place. The bedding material of the cages was changed every day. Animals handling was performed according to Good Laboratory Practice (GLP).
Procurement of Medicine: Kasis Godanti Bhasma prepared in the Pharmacy of Pt. Khushilal Sharma Govt. Ayurvedic College and Institute, Bhopal.

Composition of Medicine: Kasis Godanti Bhasma (KGB) is the combination of two major elements that is Kasis and Godanti. KGB-1 and KGB-2 prepared according to the reference of Rasamrita and $R a$ sodhhar Tantra. KGB-1 in which Kasis and Godanti use in the ratio of 1:7 and levigated with Ghritkumari Swarasa and subjected to classical puta method and form KGB-1. While KGB-2 in which Kasis and Godanti use in the equal ratio and triturating with three herbal Swarasa (Ghrit Kumara Swarasa) and decoction (Haritakikwatha and Ashwagandha Kwatha). The whole procedure to make KGB-2 require 5 classical puta.

Chemical used in experimentation: Phenylhydrazine- it is purchased from SIGMA-ALDRICH, Bangalore.

Experimental Design: Anemia was induced by intraperitoneal injection of phenylhydrazine at $40 \mathrm{mg} / \mathrm{kg}$ for 2 days. Rats were divided in six groups of four rats each. The first group is the control group received distillated water. The second group is anemic control group received only phenylhydrazine at $40 \mathrm{mg} / \mathrm{kg}$ for 2 days. Third and fourth groups received KGB $1^{\text {st }} 500$ $\mathrm{mg} / \mathrm{kg}$ and $1000 \mathrm{mg} / \mathrm{kg}$ respectively. While fifth and sixth groups received KGB $2^{\text {nd }} 500 \mathrm{mg} / \mathrm{kg}$ and 1000 $\mathrm{mg} / \mathrm{kg}$ respectively. The vehicle and the Bhasmas were administered from day 2 to day 15 after phenylhydrazine administration.

Blood samples were collected from the orbital vein on day 0 before phenylhydrazine administration, and on day $2,7,15$ after phenylhydrazine injection.

Biological procedure: Anemia is characterized by the decrease of the haemoglobin rate less than $13 \mathrm{~g} / \mathrm{dl}$ in male or $12 \mathrm{~g} / \mathrm{dl}$ in female. Between 10 to $20 \%$ of the population presents less than $10 \mathrm{~g} / \mathrm{dl}$ of haemoglobin 
in this tropical area. This chronic anemia situation exposes many people mainly pregnant women and children to develop pathologies. There are many types of anemia such as Aplastic anemia, Megaloblastic anemia, Regulatory anemia and Haemolytic anemia. Among this, Haemolytic anemia is the most frequent. In traditional medicine, Kasis Godanti Bhasma is reported to treat anemia and others associated diseases.
Experimental protocol for $\mathrm{PHZ}$ induced Anemia:

The experimental model was Phenylhydrazine induced Anemic Wistar albino rat model. The animals were divided into six group $(\mathrm{n}=4)$. Group 1 which served as non-anemic control group and group 2 which served as Anemic control group. All other group except group 1 were comprised of Anemic rats. Group-3, 4, 5, 6 received test drug.

Table 1: Shows the experimental protocol for PHZ induced anemia

\begin{tabular}{|l|l|l|l|}
\hline Sr. No. & Group & No. of Rats & Treatment \\
\hline 1. & Group-1 Normal Control & 4 & Received Distilled Water \\
\hline 2. & Group-2 Anemic Control & 4 & Phenylhydrazine $40 \mathrm{mg} / \mathrm{kg}$ \\
\hline 3. & Group-3 Anemic + Test drug & 4 & KGB-1 $500 \mathrm{mg} / \mathrm{kg}$ \\
\hline 4. & Group-4 Anemic + Test drug & 4 & KGB-1 $1000 \mathrm{mg} / \mathrm{kg}$ \\
\hline 5. & Group-5 Anemic + Test drug & 4 & KGB-2 $500 \mathrm{mg} / \mathrm{kg}$ \\
\hline 6 & Group-6 Anemic + Test drug & 4 & KGB-2 $1000 \mathrm{mg} / \mathrm{kg}$ \\
\hline
\end{tabular}

Test drug and vehicles were administered to respective groups at morning hours and continued for 15 days. Blood parameters were checked from the animals of all group on day Zero, $2^{\text {nd }}, 7^{\text {th }}$ and $15^{\text {th }}$. Weight of all animals of all group were recorded daily in the study period of 15 days.

Blood was drawn by retro-orbital puncture and collect in EDTA vial upto the level $(1 \mathrm{ml})$ that does not affect the result of blood parameter.

Body weight determination:

Weight of all rats were recorded daily.

\section{Biochemical analysis:}

- Haemoglobin

\section{Observation and Result:}

1. Effect on Haemoglobin:

Table 2: Shows Haemoglobin level of 6 groups on day $2^{\text {nd }}$ and day $7^{\text {th }}$

\begin{tabular}{|l|l|l|l|l|}
\multirow{2}{*}{ Group } & \multicolumn{2}{l|}{ Haemoglobin (gm\%) } & \multicolumn{2}{l|}{} \\
\cline { 2 - 5 } & Day 2 & Day & Change in level & \% change \\
\hline Control group & 11.86 & 11.96 & 0.1 & 0.00 \\
\hline Anemic control group & 10.7 & 10.36 & 0.34 & 0.0084 \\
\hline Anemic + KGB-1 $500 \mathrm{mg} / \mathrm{kg}$ & 9.07 & 12.7 & 3.63 & 40.02 \\
\hline Anemic + KGB-1 $1000 \mathrm{mg} / \mathrm{kg}$ & 9.93 & 9.8 & -0.1 & -1 \\
\hline Anemic + KGB-2 $500 \mathrm{mg} / \mathrm{kg}$ & 9.77 & 13.4 & 3.63 & 37.15 \\
\hline Anemic + KGB-2 $1000 \mathrm{mg} / \mathrm{kg}$ & 9.53 & 13.3 & 3.77 & 39.55 \\
\hline
\end{tabular}

- Red Blood Corpuscles

- White Blood Corpuscles

- Haematocrit

Blood parameter were analyzed on day $0,2^{\text {nd }}, 7^{\text {th }}$ and $15^{\text {th }}$ from the animals of all group.

\section{Statistical Analysis:}

Values of blood parameter of all animals of all groups were analyzed. Values are given as Mean + SEM (Standard error of the mean) and compared using oneway ANOVA with Tukey-Kramer multiple comparison test, to find the difference among all groups. Values of $\mathrm{P}<0.05$ were considered statistically significant. 
Data shows the effect of drug on Haemoglobin level on $7^{\text {th }}$ day of induction of anemia. In treated group with KGB-1 and KGB-2. $40 \%$ of hb increased in KGB-1 (500mg $/ \mathrm{kg}$ dose), $37.15 \%$ increase of $\mathrm{hb}$ in $\mathrm{KGB}-2(500 \mathrm{mg} / \mathrm{kg})$, and $39.55 \%$ of increase in $\mathrm{Hb}$ concentration of KGB-2 (1000mg/kg) dose. KGB1 with the dose of $1000 \mathrm{mg} / \mathrm{kg}$ shows no effect on Haemoglobin concentration.

- Effect of Haemoglobin level of 6 groups on day $15^{\text {th }}$ of drug administration.

Table 3: Shows Haemoglobin level of 6 groups on day $2^{\text {nd }}$ and day $15^{\text {th }}$

\begin{tabular}{|l|l|l|l|l|}
\hline \multirow{2}{*}{ Group } & \multicolumn{2}{l|}{ Haemoglobin $(\mathbf{g m} / \mathbf{d l})$} & \\
\cline { 2 - 5 } & Day 2 $^{\text {nd }}$ & Day 15 & Change in level & \% change \\
\hline Control group & 11.86 & 11.83 & 0.03 & 0.00 \\
\hline Anemic control group & 10.7 & 9.3 & 1.4 & $-13.08 \%$ \\
\hline Anemic + KGB-1 $500 \mathrm{mg} / \mathrm{kg}$ & 9.07 & 16.6 & 7.53 & 83 \\
\hline Anemic + KGB-1 $1000 \mathrm{mg} / \mathrm{kg}$ & 9.93 & 13.7 & 3.77 & 37.9 \\
\hline Anemic + KGB-2 $500 \mathrm{mg} / \mathrm{kg}$ & 9.77 & 17.3 & 7.53 & 77.07 \\
\hline Anemic + KGB-2 $1000 \mathrm{mg} / \mathrm{kg}$ & 9.53 & 15.9 & 6.37 & 66.84 \\
\hline
\end{tabular}

Data shows the effect of drug on test treated group on $15^{\text {th }}$ day of induction of anemia. $83 \%$ of $\mathrm{Hb}$ increased in KGB-1(500mg), $39 \%$ of $\mathrm{Hb}$ increased in KGB-1
(1000 mg), $77.07 \% \mathrm{Hb}$ increases in KGB-2 (500 mg) and $66.84 \% \mathrm{Hb}$ increased in KGB-2(1000 mg).

Table 4: Shows Comparison of Haemoglobin level of 6 groups on day $15^{\text {th }}$

\begin{tabular}{|l|l|l|l|l|l|}
\hline Sr. No. & Comparison Test & Mean Diff. & q value & Significance & 95\% CI of diff \\
\hline & Control group vs Anemic control & 2.500 & 2.457 & Ns & -2.335 to 7.335 \\
\hline & Control group vs Gp 3 & -4.800 & 4.717 & Ns & -9.635 to 0.03472 \\
\hline Control group vs Gp 4 & -1.900 & 1.867 & Ns & -6.735 to 2.935 \\
\hline & Control group vs Gp 5 & -5.433 & 5.339 & $*$ & -10.27 to -0.5986 \\
\hline Control group vs Gp 6 & -4.100 & 4.029 & Ns & -8.935 to 0.7347 \\
\hline Anemic control vs Gp 3 & -7.300 & 7.174 & $* *$ & -12.13 to -2.465 \\
\hline Anemic control vs Gp 4 & -4.400 & 4.324 & Ns & -9.235 to 0.4347 \\
\hline Anemic control vs Gp 5 & -7.933 & 7.796 & $* *$ & -12.77 to -3.099 \\
\hline Anemic control vs Gp 6 & -6.600 & 6.486 & $* *$ & -11.43 to -1.765 \\
\hline Gp 3 vs Gp 4 & 2.900 & 2.850 & Ns & -1.935 to 7.735 \\
\hline Gp 3 vs Gp 5 & -0.6333 & 0.6224 & Ns & -5.468 to 4.201 \\
\hline Gp 3 vs Gp 6 & 0.7000 & 0.6879 & Ns & -4.135 to 5.535 \\
\hline Gp 4 vs Gp 5 & -3.533 & 3.472 & Ns & -8.368 to 1.301 \\
\hline Gp 4 vs Gp 6 & -2.200 & 2.162 & Ns & -7.035 to 2.635 \\
\hline Gp 5 vs Gp 6 & 1.333 & 1.310 & Ns & -3.501 to 6.168 \\
\hline
\end{tabular}

*Significant, ** Highly Significant

2. Effect on Red Blood Corpuscles (RBC)

Table 5: Shows RBC level of 6 groups on day $2^{\text {nd }}$ and day $7^{\text {th }}$

\begin{tabular}{|l|l|l|l|l|}
\hline \multirow{2}{*}{ Group } & \multicolumn{4}{l}{ Red Blood Corpuscles (mil./cmm) } \\
\cline { 2 - 5 } & Day 2 $2^{\text {nd }}$ & Day $7^{\text {th }}$ & Change in level & \% change \\
\hline Control group & 5.18 & 4.92 & 0.26 & -5.01 \\
\hline Anemic control group & 4.67 & 4.1 & 0.57 & -12.20 \\
\hline Anemic + KGB-1 $500 \mathrm{mg} / \mathrm{kg}$ & 3.90 & 4.32 & 0.42 & 10.76 \\
\hline Anemic + KGB-1 $1000 \mathrm{mg} / \mathrm{kg}$ & 4.80 & 3.1 & 1.7 & -35.41 \\
\hline Anemic + KGB-2 $500 \mathrm{mg} / \mathrm{kg}$ & 3.47 & 4.46 & 0.99 & 28.5 \\
\hline Anemic + KGB-2 $1000 \mathrm{mg} / \mathrm{kg}$ & 4.08 & 4.24 & 0.16 & 3.9 \\
\hline
\end{tabular}


Data shows the effect of drug on RBC level on $7^{\text {th }}$ day of induction of anemia. In treated group with KGB-1 and KGB-2. $10.76 \%$ of RBC increased in KGB-1 (500mg $/ \mathrm{kg}$ dose), $28.5 \%$ increase of RBC in KGB-2 $(500 \mathrm{mg} / \mathrm{kg})$, and $3.9 \%$ of increase in $\mathrm{RBC}$ concentra- tion of KGB-2 (1000mg/kg) dose. KGB-1 with the dose of $1000 \mathrm{mg} / \mathrm{kg}$ shows no effect on RBC concentration.

- Effect of RBC level of 6 groups on day $15^{\text {th }}$ of drug administration

Table 6: Shows RBC level of 6 groups on day $2^{\text {nd }}$ and day $15^{\text {th }}$

\begin{tabular}{|l|l|l|l|l|}
\hline \multirow{2}{*}{ Group } & \multicolumn{4}{l|}{ Red Blood Corpuscles (mil./cmm) } \\
\cline { 2 - 5 } & Day 2 & Day 15 & Change in level & \% change \\
\hline Control group & 5.18 & 5.3 & 0.12 & 2.31 \\
\hline Anemic control group & 4.67 & 3.22 & 1.45 & 31.04 \\
\hline Anemic + KGB-1 $500 \mathrm{mg} / \mathrm{kg}$ & 3.90 & 6.46 & 2.56 & 65.64 \\
\hline Anemic + KGB-1 $1000 \mathrm{mg} / \mathrm{kg}$ & 4.80 & 5.24 & 0.44 & 9.1 \\
\hline Anemic + KGB-2 $500 \mathrm{mg} / \mathrm{kg}$ & 3.47 & 6.67 & 3.2 & 92.21 \\
\hline Anemic + KGB-2 $1000 \mathrm{mg} / \mathrm{kg}$ & 4.08 & 6.01 & 1.93 & 47.30 \\
\hline
\end{tabular}

Data shows the effect of drug on test treated group on $15^{\text {th }}$ day of induction of anemia. $65 \%$ of RBC increased in KGB-1(500mg), $9 \%$ of RBC increased in
KGB-1 (1000 mg), 92.21\% RBC increases in KGB-2 $(500 \mathrm{mg})$ and $47.30 \% \mathrm{RBC}$ increased in KGB-2(1000 $\mathrm{mg})$.

Table 7: Shows Comparison of RBC level of 6 groups on day $15^{\text {th }}$

\begin{tabular}{|l|l|l|l|l|l|}
\hline Sr. No. & Comparison Test & Mean Diff. & q value & Significance & $\mathbf{9 5 \%}$ CI of diff \\
\hline & Control Group vs Anemic control & 2.080 & 4.055 & Ns & -0.3572 to 4.517 \\
\hline & Control Group vs Group-3 & -1.160 & 2.261 & Ns & -3.597 to 1.277 \\
\hline & Control Group vs Group-4 & 0.06000 & 0.1170 & Ns & -2.377 to 2.497 \\
\hline & Control Group vs Group-5 & -1.370 & 2.671 & Ns & -3.807 to 1.067 \\
\hline Control Group vs Group-6 & -0.7100 & 1.384 & Ns & -3.147 to 1.727 \\
\hline Anemic control vs Group-3 & -3.240 & 6.316 & $* *$ & -5.677 to -0.8028 \\
\hline Anemic control vs Group-4 & -2.020 & 3.938 & Ns & -4.457 to 0.4172 \\
\hline Anemic control vs Group-5 & -3.450 & 6.725 & $* *$ & -5.887 to -1.013 \\
\hline Anemic control vs Group-6 & -2.790 & 5.439 & $*$ & -5.227 to -0.3528 \\
\hline Group-3 vs Group-4 & 1.220 & 2.378 & Ns & -1.217 to 3.657 \\
\hline Group-3 vs Group-5 & -0.2100 & 0.4094 & Ns & -2.647 to 2.227 \\
\hline Group-3 vs Group-6 & 0.4500 & 0.8772 & Ns & -1.987 to 2.887 \\
\hline & Group-4 vs Group-5 & -1.430 & 2.788 & Ns & -3.867 to 1.007 \\
\hline Group-4 vs Group-6 & -0.7700 & 1.501 & Ns & -3.207 to 1.667 \\
\hline Group-5 vs Group-6 & 0.6600 & 1.287 & Ns & -1.777 to 3.097 \\
\hline
\end{tabular}

*Significant, ** Highly Significant

- Effect on White Blood Corpuscles (WBC)

Table 8: Shows WBC level of 6 groups on day $2^{\text {nd }}$ and day $7^{\text {th }}$

\begin{tabular}{|l|l|l|l|l|}
\hline \multirow{2}{*}{ Group } & \multicolumn{3}{l}{ White Blood Corpuscles (/cmm) } & \\
\cline { 2 - 4 } & Day 2 $^{\text {nd }}$ & Day $^{\text {th }}$ & Change in level & \% change \\
\hline Control group & 7933 & 6733 & 1200 & 15 \\
\hline Anemic control group & 12966 & 8633 & 4333 & 33.41 \\
\hline Anemic + KGB-1 $500 \mathrm{mg} / \mathrm{kg}$ & 18233 & 4566 & 13667 & 74.95 \\
\hline Anemic + KGB-1 $1000 \mathrm{mg} / \mathrm{kg}$ & 17333 & 5866 & 11467 & 66.15 \\
\hline Anemic + KGB-2 $500 \mathrm{mg} / \mathrm{kg}$ & 30300 & 5700 & 24600 & 81.18 \\
\hline Anemic + KGB-2 $1000 \mathrm{mg} / \mathrm{kg}$ & 20066 & 4400 & 15666 & 78.07 \\
\hline
\end{tabular}


Data shows the effect of drug on WBC level on $7^{\text {th }}$ day of induction of anemia. In treated group with KGB-1 and KGB-2. $74.95 \%$ of WBC decreased in $\mathrm{KGB}-1$ (500mg $/ \mathrm{kg}$ dose), $66.15 \%$ decrease in WBC of KGB-1 (1000 mg/kg), and $81.18 \%$ of decrease in
WBC concentration of $\mathrm{KGB}-2 \quad(500 \mathrm{mg} / \mathrm{kg})$ dose. $78.07 \%$ decrease of WBC observed in KGB-2 (1000mg) dose.

- Effect of WBC level of 6 groups on day $15^{\text {th }}$ of drug administration

Table 9: Shows WBC level of 6 groups on day $2^{\text {nd }}$ and day $15^{\text {th }}$

\begin{tabular}{|l|l|l|l|l|}
\hline \multirow{2}{*}{ Group } & \multicolumn{3}{l}{ White Blood Corpuscles $(/ \mathbf{c m m})$} & \\
\cline { 2 - 5 } & Day 2 $^{\text {nd }}$ & Day 15 $^{\text {th }}$ & Change in level & \% change \\
\hline Control group & 7933 & 5333 & 2600 & 32.77 \\
\hline Anemic control group & 12966 & 12866 & 100 & 0.77 \\
\hline Anemic + KGB-1 $500 \mathrm{mg} / \mathrm{kg}$ & 18233 & 9166 & 9067 & 49.72 \\
\hline Anemic + KGB-1 $1000 \mathrm{mg} / \mathrm{kg}$ & 17333 & 4500 & 12833 & 74 \\
\hline Anemic + KGB-2 $500 \mathrm{mg} / \mathrm{kg}$ & 30300 & 6866 & 23434 & 77.33 \\
\hline Anemic + KGB-2 $1000 \mathrm{mg} / \mathrm{kg}$ & 20066 & 5633 & 14433 & 71.92 \\
\hline
\end{tabular}

Data shows the effect of drug on WBC level on $15^{\text {th }}$ day of induction of anemia. In treated group with KGB-1 and KGB-2. 49.72\% of WBC decreased in KGB-1 (500mg $/ \mathrm{kg}$ dose), $74 \%$ decrease in WBC of
KGB-1 (1000 $\mathrm{mg} / \mathrm{kg})$, and $77.33 \%$ of decrease in WBC concentration of KGB-2 $(500 \mathrm{mg} / \mathrm{kg})$ dose. $71.92 \%$ decrease of WBC observed in KGB-2 (1000mg) dose.

Table 10: Shows Comparison of WBC level of 6 groups on day $15^{\text {th }}$

\begin{tabular}{|c|c|c|c|c|c|}
\hline \multirow[t]{16}{*}{ Sr. No. } & Comparison Test & Mean Diff. & q value & Significance & $95 \% \mathrm{CI}$ of diff \\
\hline & Control group vs Anemic Control group & -7533 & 3.274 & Ns & -18467 to 3400 \\
\hline & Control group vs Gp 3 & -3833 & 1.666 & Ns & -14767 to 7100 \\
\hline & Control group vs Gp 4 & 833.3 & 0.3621 & Ns & -10100 to 11767 \\
\hline & Control group vs Gp 5 & -1533 & 0.6663 & Ns & -12467 to 9400 \\
\hline & Control group vs Gp 6 & -300.0 & 0.1304 & Ns & -11233 to 10633 \\
\hline & Anemic Control group vs Gp 3 & 3700 & 1.608 & Ns & -7233 to 14633 \\
\hline & Anemic Control group vs $\mathrm{Gp} 4$ & 8367 & 3.636 & Ns & -2567 to 19300 \\
\hline & Anemic Control group vs Gp 5 & 6000 & 2.607 & Ns & -4933 to 16933 \\
\hline & Anemic Control group vs Gp 6 & 7233 & 3.143 & Ns & -3700 to 18167 \\
\hline & Gp 3 vs Gp 4 & 4667 & 2.028 & Ns & -6267 to 15600 \\
\hline & Gp 3 vs Gp 5 & 2300 & 0.9994 & Ns & -8633 to 13233 \\
\hline & Gp 3 vs Gp 6 & 3533 & 1.535 & Ns & -7400 to 14467 \\
\hline & Gp 4 vs Gp 5 & -2367 & 1.028 & Ns & -13300 to 8567 \\
\hline & Gp 4 vs Gp 6 & -1133 & 0.4925 & Ns & -12067 to 9800 \\
\hline & Gp 5 vs Gp 6 & 1233 & 0.5359 & Ns & -9700 to 12167 \\
\hline
\end{tabular}

*Significant, ** Highly Significant

3. Effect on Haematocrit (HCT):

Table 11: Shows HCT level of 6 groups on day $2^{\text {nd }}$ and day $7^{\text {th }}$

\begin{tabular}{|l|l|l|l|l|}
\multirow{2}{*}{ Group } & \multicolumn{2}{|l|}{ Haematocrit (\%) } & \\
\cline { 2 - 5 } & Day 2 $^{\text {nd }}$ & Day $\mathbf{7}^{\text {th }}$ & Change in level & \% change \\
\hline Control group & 34 & 40.46 & 6.46 & 19 \\
\hline Anemic control group & 27.3 & 27.06 & 0.24 & 0.87 \\
\hline Anemic + KGB-1 $500 \mathrm{mg} / \mathrm{kg}$ & 20 & 37.9 & 17.9 & 89.5 \\
\hline Anemic + KGB-1 $1000 \mathrm{mg} / \mathrm{kg}$ & 24 & 31.46 & 7.46 & 31.08 \\
\hline Anemic + KGB-2 $500 \mathrm{mg} / \mathrm{kg}$ & 18.27 & 39.86 & 21.59 & 118.17 \\
\hline Anemic + KGB-2 $1000 \mathrm{mg} / \mathrm{kg}$ & 20.64 & 40.71 & 20.06 & 97.18 \\
\hline
\end{tabular}


Data shows the effect of drug on Haematocrit level on $7^{\text {th }}$ day of induction of anemia. In treated group with KGB-1 and KGB-2. $89.5 \%$ of Haematocrit level increased in KGB-1 (500mg $/ \mathrm{kg}$ dose), $31.08 \%$ increase of haematocrit level in KGB-1 (1000 mg) dose,
$118.17 \%$ increase of Haematocrit level in KGB-2 (500 $\mathrm{mg} / \mathrm{kg}$ ), and $97.18 \%$ of increase in Haematocrit level concentration of KGB-2 $(1000 \mathrm{mg} / \mathrm{kg})$ dose.

- Effect of HCT level of 6 groups on day $15^{\text {th }}$ of drug administration

Table 12: Shows HCT level of 6 groups on day $2^{\text {nd }}$ and day $15^{\text {th }}$

\begin{tabular}{|l|l|l|l|l|}
\hline \multirow{2}{*}{ Group } & \multicolumn{3}{l|}{ Haematocrit (\%) } & \% change \\
\cline { 2 - 5 } & Day 2 & Day $\mathbf{1 5}^{\text {th }}$ & Change in level & 0 \\
\hline Control group & 34 & 34 & 0 & 0 \\
\hline Anemic control group & 27.3 & 27.3 & 0 & 146 \\
\hline Anemic + KGB-1 $500 \mathrm{mg} / \mathrm{kg}$ & 20 & 49.2 & 29.2 & 75.8 \\
\hline Anemic + KGB-1 $1000 \mathrm{mg} / \mathrm{kg}$ & 24 & 42.2 & 18.2 & 188.45 \\
\hline Anemic + KGB-2 $500 \mathrm{mg} / \mathrm{kg}$ & 18.27 & 52.7 & 34.43 & 130.62 \\
\hline Anemic + KGB-2 $1000 \mathrm{mg} / \mathrm{kg}$ & 20.64 & 47.6 & 26.96 & \\
\hline
\end{tabular}

Data shows the effect of drug on Haematocrit level on $15^{\text {th }}$ day of induction of anemia. In treated group with KGB-1 and KGB-2. 146\% of Haematocrit level increased in KGB-1 (500mg $/ \mathrm{kg}$ dose), $75.8 \%$ increase of haematocrit level in KGB-1 (1000 mg) dose, $188.45 \%$ increase of Haematocrit level in KGB-2 (500 $\mathrm{mg} / \mathrm{kg}$ ), and $130.62 \%$ of increase in Haematocrit level concentration of KGB-2 $(1000 \mathrm{mg} / \mathrm{kg})$ dose.

Table 13: Shows Comparison of HCT level of 6 groups on day $15^{\text {th }}$

\begin{tabular}{|l|l|l|l|l|l|}
\hline Sr. No. & Comparison Test & Mean Diff. & q value & Significance & 95\% CI of diff \\
\hline 1. & Control Group vs Anemic control group & 6.700 & 2.083 & Ns & -8.581 to 21.98 \\
\hline 2. & Control Group vs Gp-3 & -15.33 & 4.767 & $*$ & -30.61 to -0.05184 \\
\hline 3. & Control Group vs Gp-4 & -8.200 & 2.549 & Ns & -23.48 to 7.081 \\
\hline 4. & Control Group vs Gp-5 & -18.70 & 5.814 & $*$ & -33.98 to -3.419 \\
\hline 5. & Control Group vs Gp-6 & -13.60 & 4.228 & Ns & -28.88 to 1.682 \\
\hline 6. & Anemic control group vs Gp-3 & -22.03 & 6.850 & $* *$ & -37.31 to -6.752 \\
\hline 7. & Anemic control group vs Gp-4 & -14.90 & 4.632 & Ns & -30.18 to 0.3815 \\
\hline 8. & Anemic control group vs Gp-5 & -25.40 & 7.897 & $* *$ & -40.68 to -10.12 \\
\hline 9. & Anemic control group vs Gp-6 & -20.30 & 6.311 & $* *$ & -35.58 to -5.018 \\
\hline 10. & Gp-3 vs Gp-4 & 7.133 & 2.218 & Ns & -8.148 to 22.41 \\
\hline 11. & Gp-3 vs Gp-5 & -3.367 & 1.047 & Ns & -18.65 to 11.91 \\
\hline 12. & Gp-3 vs Gp-6 & 1.733 & 0.5389 & Ns & -13.55 to 17.01 \\
\hline 13. & Gp-4 vs Gp-5 & -10.50 & 3.264 & Ns & -25.78 to 4.781 \\
\hline 14. & Gp-4 vs Gp-6 & -5.400 & 1.679 & Ns & -20.68 to 9.882 \\
\hline 15. & Gp-5 vs Gp-6 & 5.100 & 1.586 & Ns & -10.18 to 20.38 \\
\hline
\end{tabular}

*Significant, ** Highly Significant 

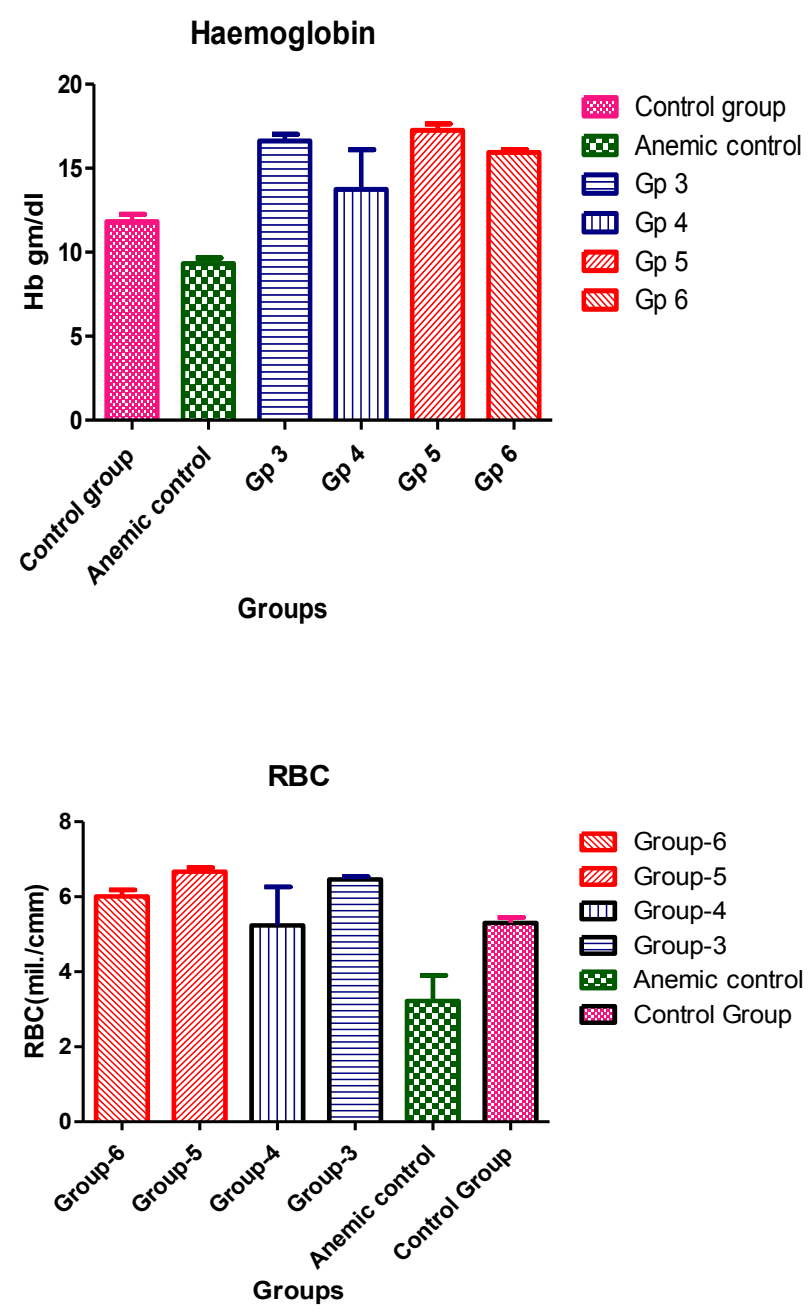

\section{DISCUSSION}

The experimental study of KGB-1 and KGB-2 is satisfactory and shows better activity towards anti anemic effect. The effect of test drug at two different doses and in between two different formulations comparing reference standard on blood parameter like $\mathrm{Hb}, \mathrm{RBC}$, WBC, Haematocrit (HCT) value were evaluated at various intervals during the course of treatment.
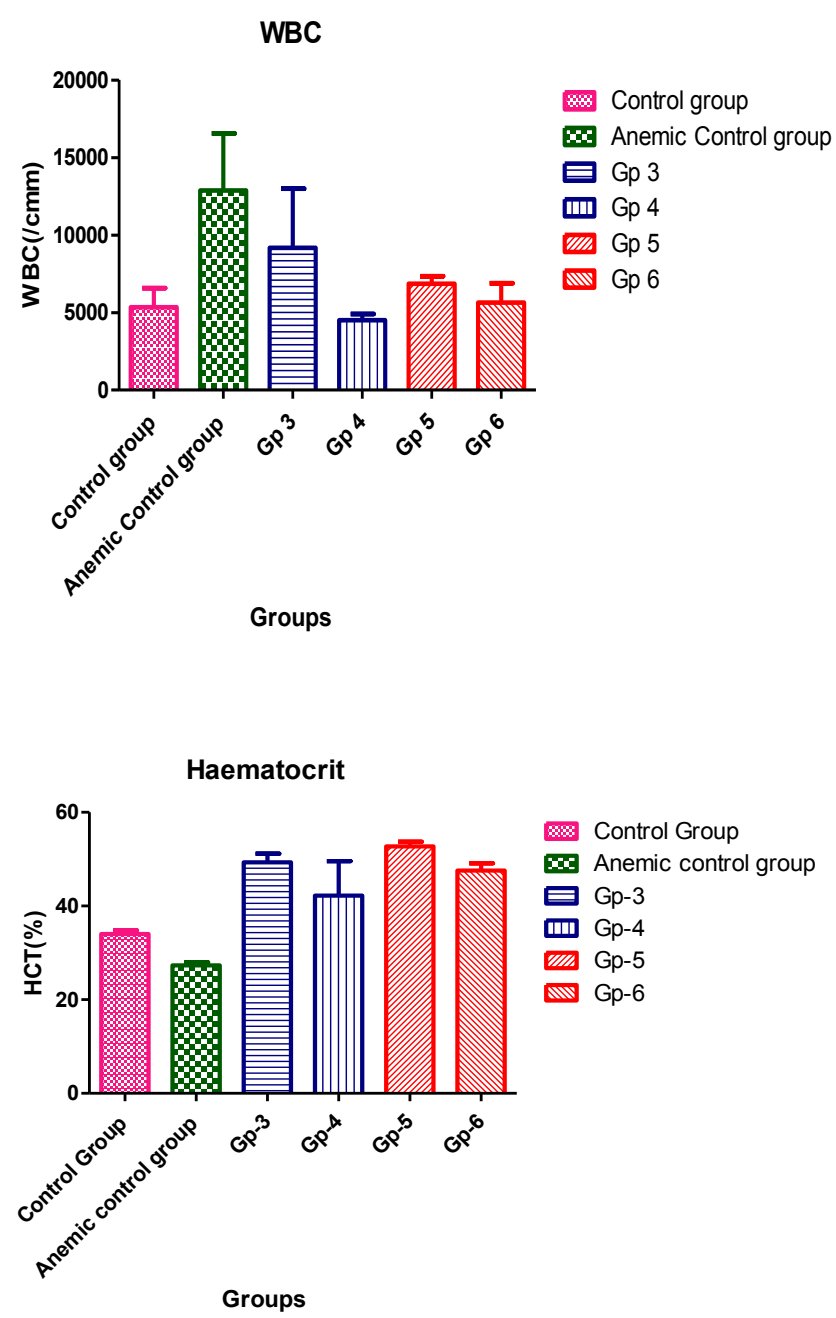

On $7^{\text {th }}$ day, Anti anemic effect was observed in KGB1 and KGB-2 with different doses of 500mg and $1000 \mathrm{mg}$. Experimental data indicate that during the earlier stages of anemia test drug is quite effective. On comparing the KGB-1 $500 \mathrm{mg}$, KGB-1 $1000 \mathrm{mg}$, KGB-2 $500 \mathrm{mg}$ and KGB-2 1000mg in Group-3,4,5,6 respectively.

The effect of different dose and different formulation of $\mathrm{KGB}$ on $\mathrm{Hb}$ are as follows -

Table 14: Shows the increase of $\mathrm{Hb} \%$ from day $7^{\text {th }}$ to day $15^{\text {th }}$

\begin{tabular}{|l|l|l|l|}
\hline Sr. No. & Formulation & $\mathbf{7}^{\text {th }}$ day & $\mathbf{1 5}^{\text {th }}$ day \\
\hline 1. & KGB-1 $500 \mathrm{mg}$ & $40.00 \%$ & $83.00 \%$ \\
\hline 2. & KGB-1 $1000 \mathrm{mg}$ & - & $37.90 \%$ \\
\hline 3. & KGB-2 $500 \mathrm{mg}$ & $37.15 \%$ & $77.07 \%$ \\
\hline 4. & KGB-2 $1000 \mathrm{mg}$ & $39.55 \%$ & $66.84 \%$ \\
\hline
\end{tabular}


On $7^{\text {th }}$ day KGB-1 500 shows better significant result. KGB-1 1000 have no significant result. While KGB-2 500 and KGB-2 1000 both shows significant result as compare to KGB-1. On $15^{\text {th }}$ day, anti-anemic effect of KGB-1 and KGB-2 with both the doses shows significant result. KGB-1 500, KGB-2 500 and 1000 shows highly significant result as compare to KGB-1 1000 dose. KGB-1 500 treated gp is highly significant as compare to KGB-2 500. When comparing KGB-1 formulation with KGB-2 it is found that KGB-2 with both doses 500 and $1000 \mathrm{mg}$ is highly significant as compare to KGB-1 both doses.

- Effect of KGB-1 and KGB-2 on RBC level are as follows-

Table 15: Shows the increase of RBC level from day $7^{\text {th }}$ to day $15^{\text {th }}$

\begin{tabular}{|l|l|l|l|}
\hline Sr. No. & Formulation & $\mathbf{7}^{\text {th }}$ day & $\mathbf{1 5}^{\text {th }}$ day \\
\hline 1. & KGB-1 $500 \mathrm{mg}$ & $10.76 \%$ & $65.64 \%$ \\
\hline 2. & KGB-1 $1000 \mathrm{mg}$ & - & $09.10 \%$ \\
\hline 3. & KGB-2 $500 \mathrm{mg}$ & $28.50 \%$ & $92.21 \%$ \\
\hline 4. & KGB-2 $1000 \mathrm{mg}$ & $03.90 \%$ & $47.30 \%$ \\
\hline
\end{tabular}

When all group are statistically compared result shows that KGB-1 500 and KGB-2 500 are highly significant while KGB-2 1000 is only significant. Less dose of KGB-2 is more efficacious then high dose.
- Effect of KGB-1 and KGB-2 on WBC level are as follows-

Table 16: Shows the increase of WBC level from day $7^{\text {th }}$ to day $15^{\text {th }}$

\begin{tabular}{|l|l|l|l|}
\hline Sr. No. & Formulation & $\mathbf{7}^{\text {th }}$ day & $\mathbf{1 5}^{\text {th }}$ day \\
\hline 1. & KGB-1 $500 \mathrm{mg}$ & $74.95 \%$ & $49.72 \%$ \\
\hline 2. & KGB-1 $1000 \mathrm{mg}$ & $66.15 \%$ & $74.00 \%$ \\
\hline 3. & KGB-2 $500 \mathrm{mg}$ & $81.18 \%$ & $77.33 \%$ \\
\hline 4. & KGB-2 $1000 \mathrm{mg}$ & $78.07 \%$ & $71.92 \%$ \\
\hline
\end{tabular}

When all groups are compared the result is nonsignificant and it shows that medicine is quite effective to treat any infection. KGB-1 500 is better than KGB-1 1000, KGB-2 500 is better than KGB-2 1000 and on comparing KGB-1 and KGB-2, KGB-2 with both doses shows better effect.

- Effect of KGB-1 and KGB-2 on Haematocrit value are as follows-

Table 17: Shows the increase of HCT level from day $7^{\text {th }}$ to day $15^{\text {th }}$

\begin{tabular}{|l|l|r|r|}
\hline Sr. No. & Formulation & $\mathbf{7}^{\text {th }}$ day & $\mathbf{1 5}^{\text {th }}$ day \\
\hline 1. & KGB-1 $500 \mathrm{mg}$ & $89.50 \%$ & $146.00 \%$ \\
\hline 2. & KGB-1 $1000 \mathrm{mg}$ & $31.08 \%$ & $75.80 \%$ \\
\hline 3. & KGB-2 $500 \mathrm{mg}$ & $118.17 \%$ & $188.45 \%$ \\
\hline 4. & KGB-2 $1000 \mathrm{mg}$ & $97.18 \%$ & $130.62 \%$ \\
\hline
\end{tabular}

When all groups statistically compared then KGB-1 500, KGB-2 500 and KGB-2 1000 shows highly significant result. On comparing KGB-1 500 and 1000, KGB-1 $500 \mathrm{mg}$ dose is much more effective than $1000 \mathrm{mg}$ dose and on comparing KGB-2 500 and 1000, KGB-2 $500 \mathrm{mg}$ dose is much more effective than 1000 mg dose. On comparing KGB-1 and KGB2, the KGB-2 with both doses much more significant and effective medicine.

Statistical analysis of $\mathrm{Hb}$ level on $15^{\text {th }}$ day, $\mathrm{P}$ value is 0.0008 which is more significant for Group-3, 5, and 6. Statistical analysis of RBC value on $15^{\text {th }}$ day, $\mathrm{P}$ val- 
ue is 0.0053 which is more significant for Group-3, 5, and 6

Statistical analysis of WBC level on $15^{\text {th }}$ day, P value is 0.1767 which is non-significant for all Group it indicates that formulation has potency to decrease the WBC level. Statistical analysis of HCT level on $15^{\text {th }}$ day, $\mathrm{P}$ value is 0.0008 which is more significant for Group-3, 5, and 6.

Note - In Modern text it is clearly mention that calcium and iron compete for the same receptor and as a result calcium inhibit the absorption of iron when taken together. In pregnancy period pregnant women are also advised to take calcium and iron preparation on different time interval.

In present study, the formulation prepared named as "Kasis Godanti Bhasma" contained both iron and calcium as main ingredients and indicated therapeutically in the management of various diseases viz. Pandu, Shawasa, Kasa, Yakrutaroga etc.

By doing the experimental study on this formulation. It is easy to say that both iron and calcium not interacting each other and calcium not inhibit the absorption of iron because they are in compound form in the formulation and particle size is in nanometer which is responsible for increasing its bioavailability and fast absorption on target organ.

This formulation is effective in treating anemia and also treat the infection by lowering the WBC level in animal model (wistar albino rats).

\section{CONCLUSION}

Experimental study of KGB-1 and KGB-2 shows satisfactory result. On comparing result of KGB-1 and KGB-2. KGB-2 with both doses of $500 \mathrm{mg}$ and $1000 \mathrm{mg}$ shows significant result in Anti-anemic effect. While in KGB-1, only $500 \mathrm{mg}$ dose shows the significant result in Anti-anemic effect. On comparing dose of both the samples $500 \mathrm{mg}$ dose of KGB-1 and KGB-2 shows satisfactory result.

\section{REFERENCES}

1. Aboudoulatif Diallo et all, FITOTERAPIA (Elsvier) Effect of Tectonagrandis on PHZ induced anemia.
2. http://jjbs.hu.edu.jo/files/v1 1n1/Paper\%20Numb er\%2010m.pdf

\section{Source of Support: Nil \\ Conflict of Interest: None Declared}

How to cite this URL: Vidhiya Malviya et al: An Experimental Study On Two Samples Of Kasis Godanti Bhasma Prepared By Different Methods w.s.r. to Anemia. International Ayurvedic Medical Journal \{online\} 2021 \{cited January, 2021\} Available from: http://www.iamj.in/posts/images/upload/_.pdf 